\title{
A Two-Phase or Tiered Caddo Mound at The Camp Joy Site (41UR144), Lake 0' the Pines
}

Mike Turner

Unknown

Follow this and additional works at: https://scholarworks.sfasu.edu/ita

Part of the American Material Culture Commons, Archaeological Anthropology Commons, Environmental Studies Commons, Other American Studies Commons, Other Arts and Humanities Commons, Other History of Art, Architecture, and Archaeology Commons, and the United States History Commons

Tell us how this article helped you.

This Article is brought to you for free and open access by the Center for Regional Heritage Research at SFA ScholarWorks. It has been accepted for inclusion in Index of Texas Archaeology: Open Access Gray Literature from the Lone Star State by an authorized editor of SFA ScholarWorks. For more information, please contact cdsscholarworks@sfasu.edu. 


\section{A Two-Phase or Tiered Caddo Mound at The Camp Joy Site (41UR144), Lake 0'}

the Pines

\section{Creative Commons License}

\section{(c) (1) \&}

This work is licensed under a Creative Commons Attribution-NonCommercial 4.0 International License 


\title{
A Two-Phase or Tiered Caddo Mound at The Camp Joy Site (41UR144), Lake $O^{\prime}$ the Pines
}

by

Mike Turner

As the United States expanded in the late eighteenth century and through most of the nineteenth century, much interest and question was raised over the increasing numbers of earthen mounds and earthen constructions encountered by the settlers moving westward across the southeastern woodlands. Mounds? Mound builders? Enough questions were raised about their origins that in 1881, the Division of Mound Exploration of the Bureau of Ethnology, Smithsonian Institution, was established to address and resolve these issues. The work of the Division of Mound Exploration can be considered the first "modern archeology" done in the United States (Smith 1985). Their mound research covered the Dakotas to Texas and all points east.

The final research report by Division Head, Cyrus Thomas, was published as the Twelfth Annual Report of the Bureau of Ethnology (Thomas 1894). In this report, Thomas (1894:591) mentions in the Gulf District that:

\begin{abstract}
some two or three mounds of peculiar form have been discovered in Mississippi and the Arkansas district that have not been observed elsewhere in the mound area. These may be described as earthen platforms surmounted by a conical mound or a conical mound surrounded by a terrace. Sometimes the conical mound is small in proportion to the platform and is not central...A double mound of this type, or mound with two apices, has been observed in western Mississippi.
\end{abstract}

The primary purpose of this report is to make known the occurrence of a two-phase Caddoan earthen mound in Upshur County. Furthermore, this report seeks to add this site to the inventory of known archeological resources of the Cypress Creek basin (see also Thurmond 1990). Available data relevant to the Cypress Basin and the immediate area of the site has also been summarized and reported here to suggest chronological associations for the two-phase mound.

\section{THE CAMP JOY MOUND}

The Camp Joy Mound is a two-phase or "two-tiered" Caddoan earthen mound located in northeast Upshur County (Turner 1993). The mound, on U.S. Army Corps of Engineers, Fort Worth District property, sits adjacent to a small spring branch that flows east into the now-inundated Big Cypress Creek at Lake O' the Pines (Figure 1). 


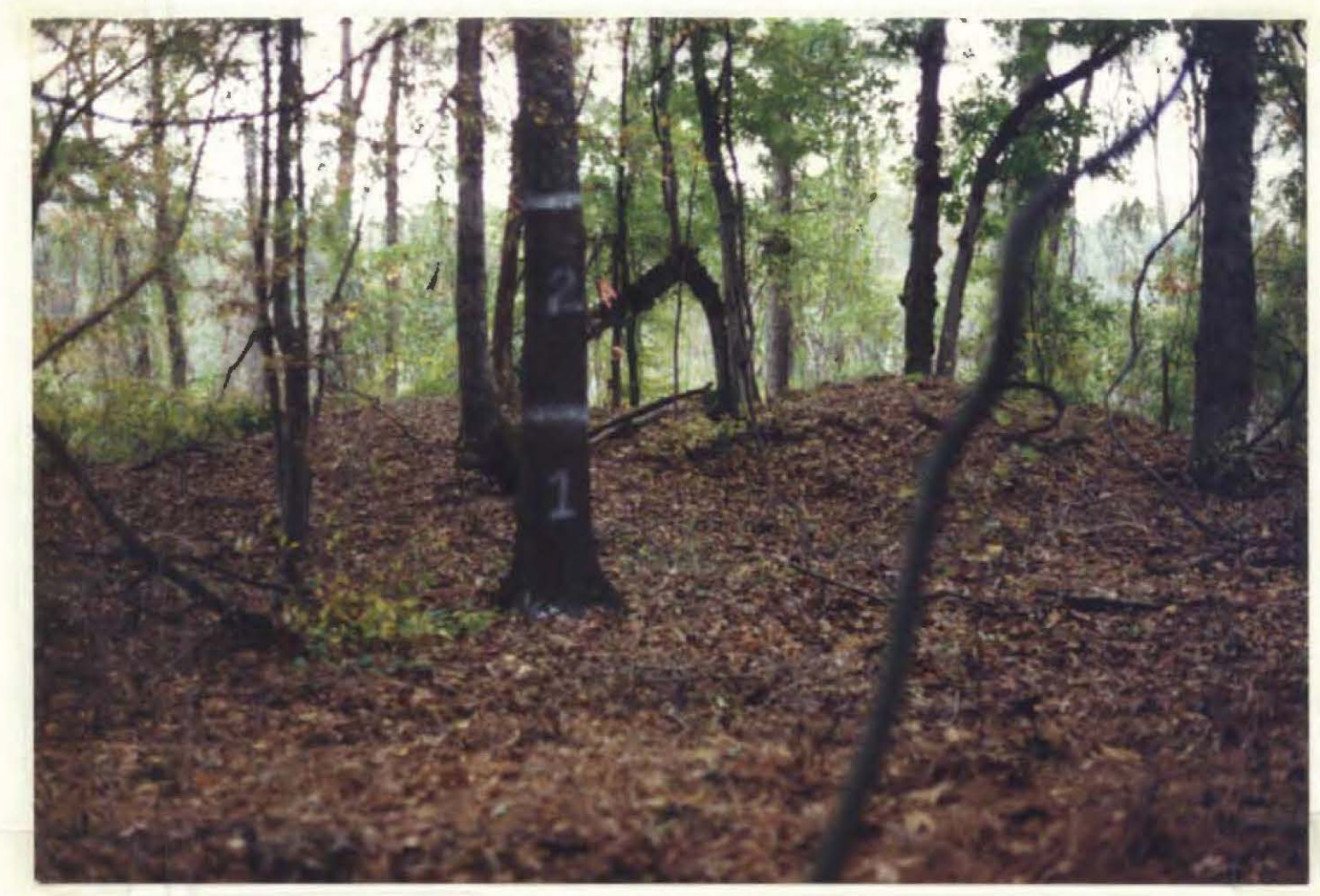

Figure 1. Photograph of the Camp Joy Mound. Tree in foreground is marked in meters.

The basal mound, referred to here as the "platform" mound, is approximately $35 \mathrm{x}$ $18 \mathrm{~m}$ in size, rising some $1.13 \mathrm{~m}$ in height above the floodplain of the unnamed spring branch. The west corner of the platform is not well defined, but gently blends into an eastwest trending alluvial terrace. A lower alluvial terrace runs within $18 \mathrm{~m}$ of the mound's north corner (Figure 2). This terrace tapers off into the floodplain about $45 \mathrm{~m}$ from the east platform corner.

The top-tier of the mound measures approximately $10 \times 11 \mathrm{~m}$, being roughly centered along the western side of the platform mound. This part of the mound rises another $1.10 \mathrm{~m}$ above the platform mound, and it is separated from it by a $7 \mathrm{~cm}$ thick lens of charcoal. All indications are that this charcoal represents a possible burned structure capped by the small mound. Both phases of mound construction at this site have level and flat surfaces.

\section{SITE INVESTIGATIONS}

Early in 1984, I found this mound while hunting along the shoreline of Lake $\mathrm{O}^{\prime}$ the Pines. Used to seeing round to oval-shaped mounds, the more rectangular shape and 
distinct edges of this mound construction readily caught my attention. Upon examination, I was surprised to find it to be an Indian mound rather than an old house pad.

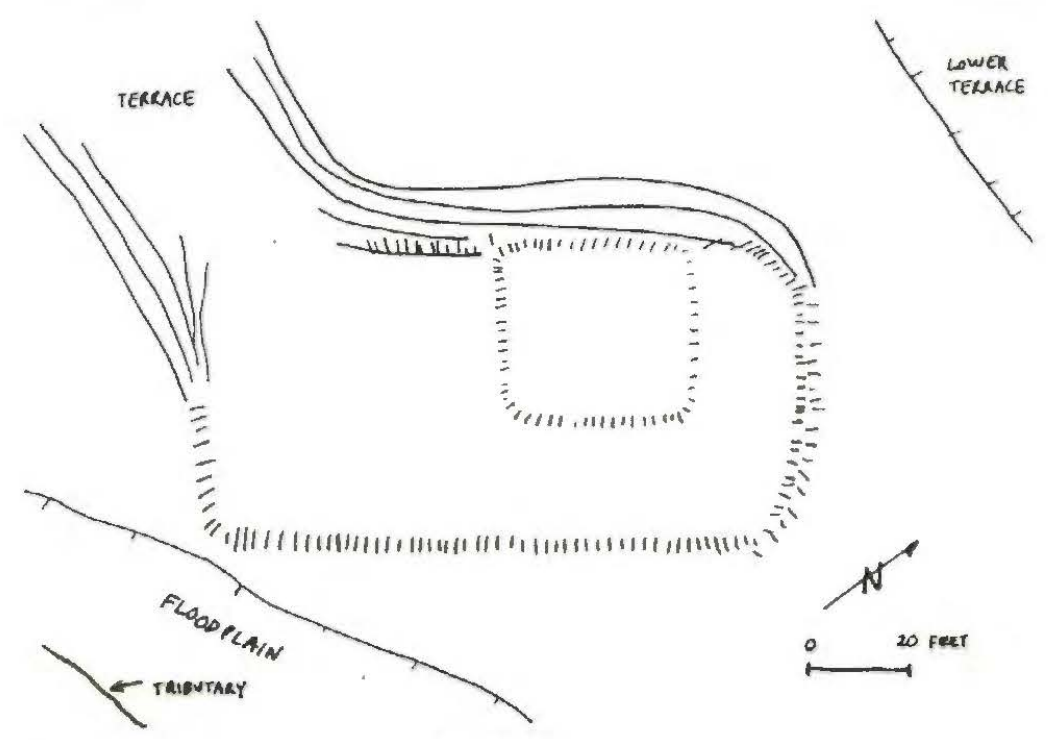

Figure 2. 1984 Plan of the Camp Joy Mound.

The two-tiered mound was the first I had seen, and the only one I know of in the Cypress Basin. Its virtual pristine condition was also surprising. Aside from some erosion along the edges of the platform due to lake inundation, the mound was apparently undisturbed (see Figure 2).

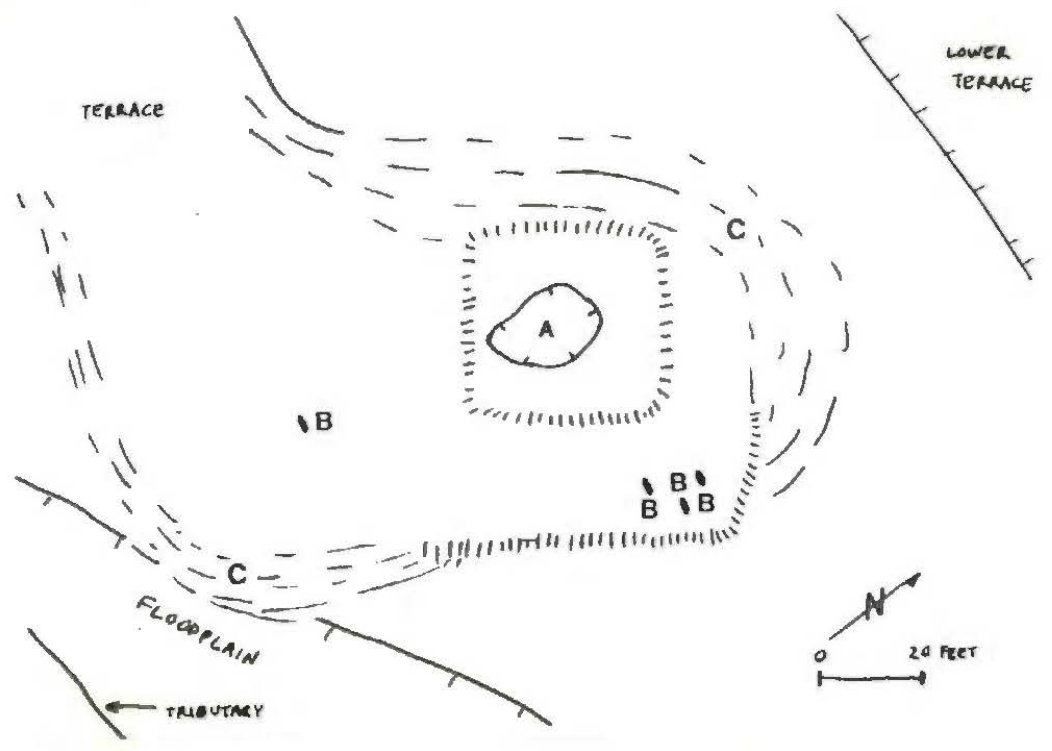

Figure 3. 1988 Plan of the Camp Joy Mound. A is the open pit, B are the open potholes (burials) and $\mathrm{C}$ indicates areas of active erosion due to flooding. 
My second visit to the site was in 1988 . The situation was very different than in 1984. The top mound had a $2.5 \mathrm{~m}$ wide open pit in its center that was $2 \mathrm{~m}$ deep. On the flattened surface of the platform were four open potholes, three on the eastern corner and one close to the south corner. All four appeared to be east-west oriented burial pits, but no associated cultural materials were observed (Figure 3 ).

Also, due to heavy rains and high water from 1986-1988, a more serious problem with erosion had begun. The edges along the spring and on the north corner of the platform, where the water rises between the two alluvial terraces, had begun to severely erode (see Figure 3).

Finally, in early October 1992, Dr. Tim Perttula of the Texas Historical Commission (THC) and Bo Nelson, then president of the Northeast Texas Archeological Society (NETAS), visited this unusual earthen mound with the author. At the behest of the THC, in November 1992, NETAS members Kevin King and Bo Nelson joined with me in surveying and officially recording the site (Figure 4).

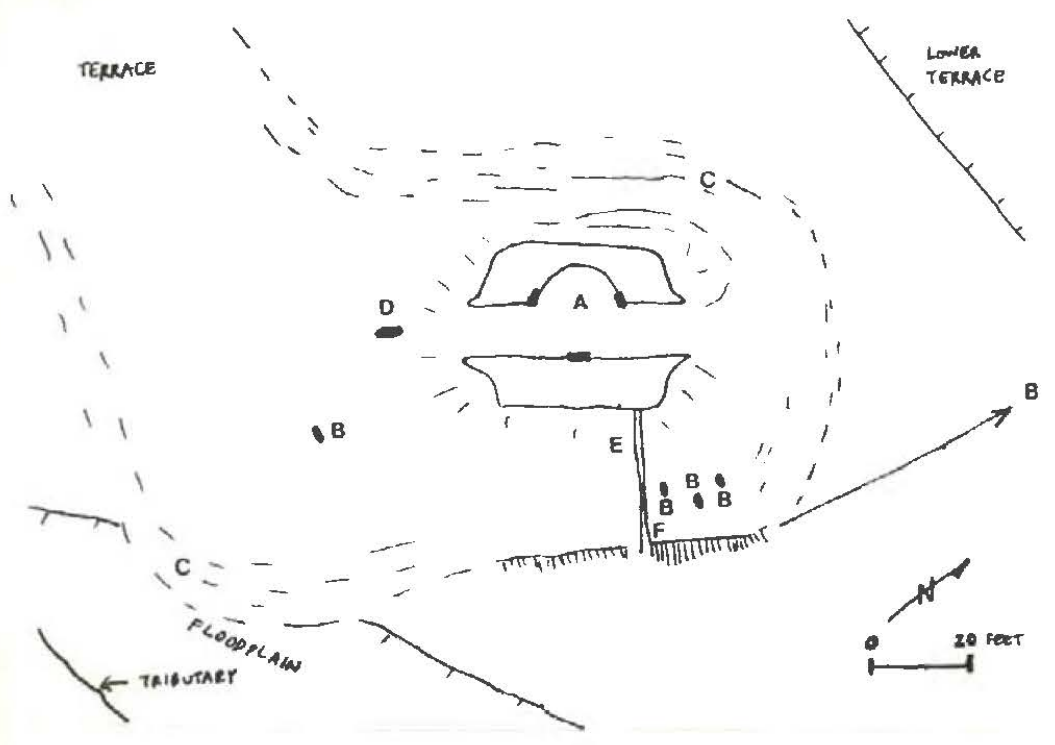

Figure 4. 1992 Plan of the Camp Joy Mound. A is the open trench, B are the open potholes (burials), C represent areas of erosion caused by flooding, $\mathrm{D}$ is a new pothole (burial), $\mathrm{E}$ is the open drainage ditch, and $\mathrm{F}$ is the location of a brushed pottery sherd. The dark rectangles around the open trench are the profiles shown in Figure 8 and 9.

By this time, the site damage by both looting and erosion had escalated. The open pit in the top mound was now an open trench about $3 \mathrm{~m}$ wide across the entire small mound (Figure 5). An open pothole (burial) was exposed at the southwest edge of this trench (Figure 6). There was also a second open pothole or burial noted on the lower alluvial terrace $30 \mathrm{~m}$ north-northeast of the platform's east corner (Figure 7). 


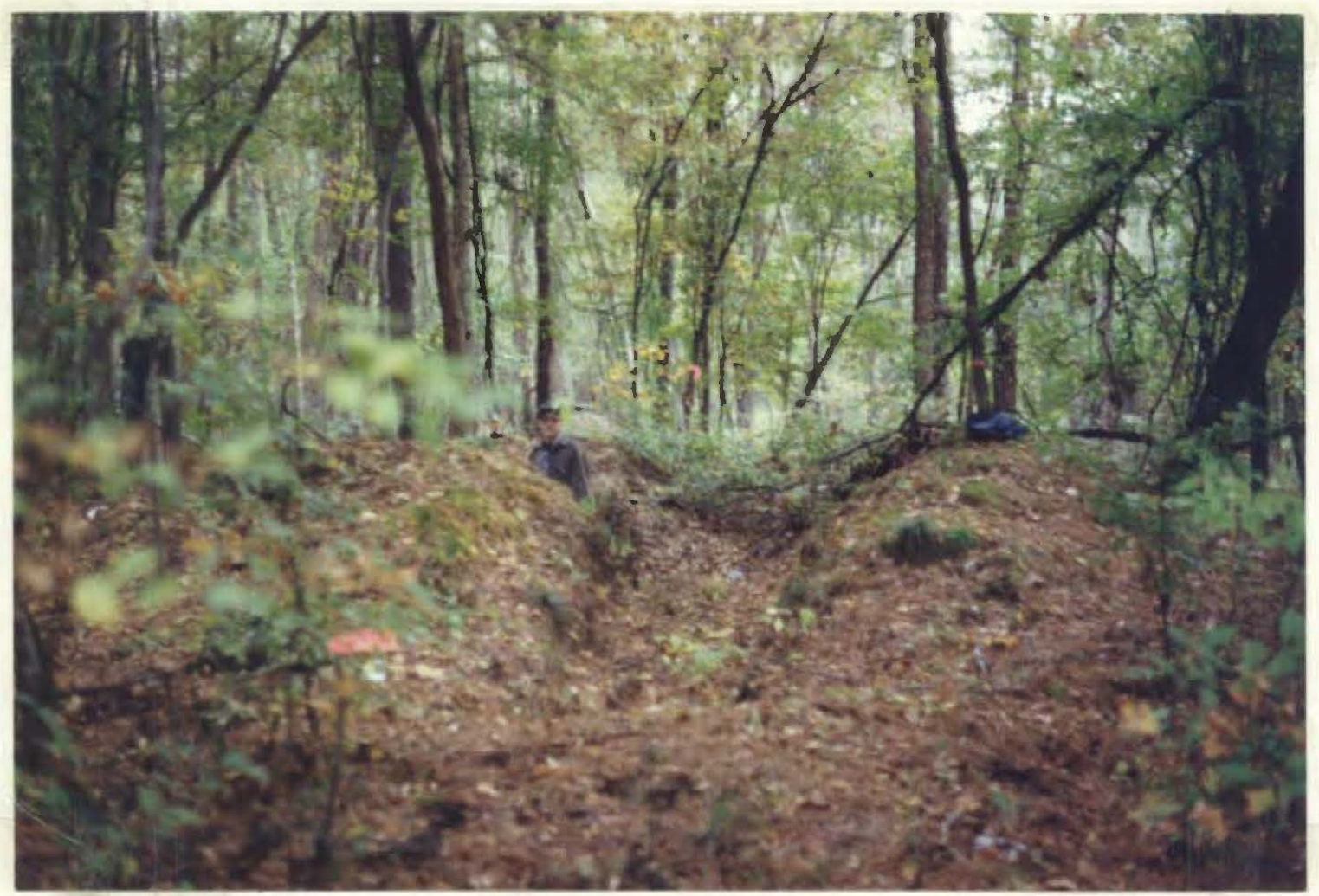

Figure 5. Open trench in the top mound.

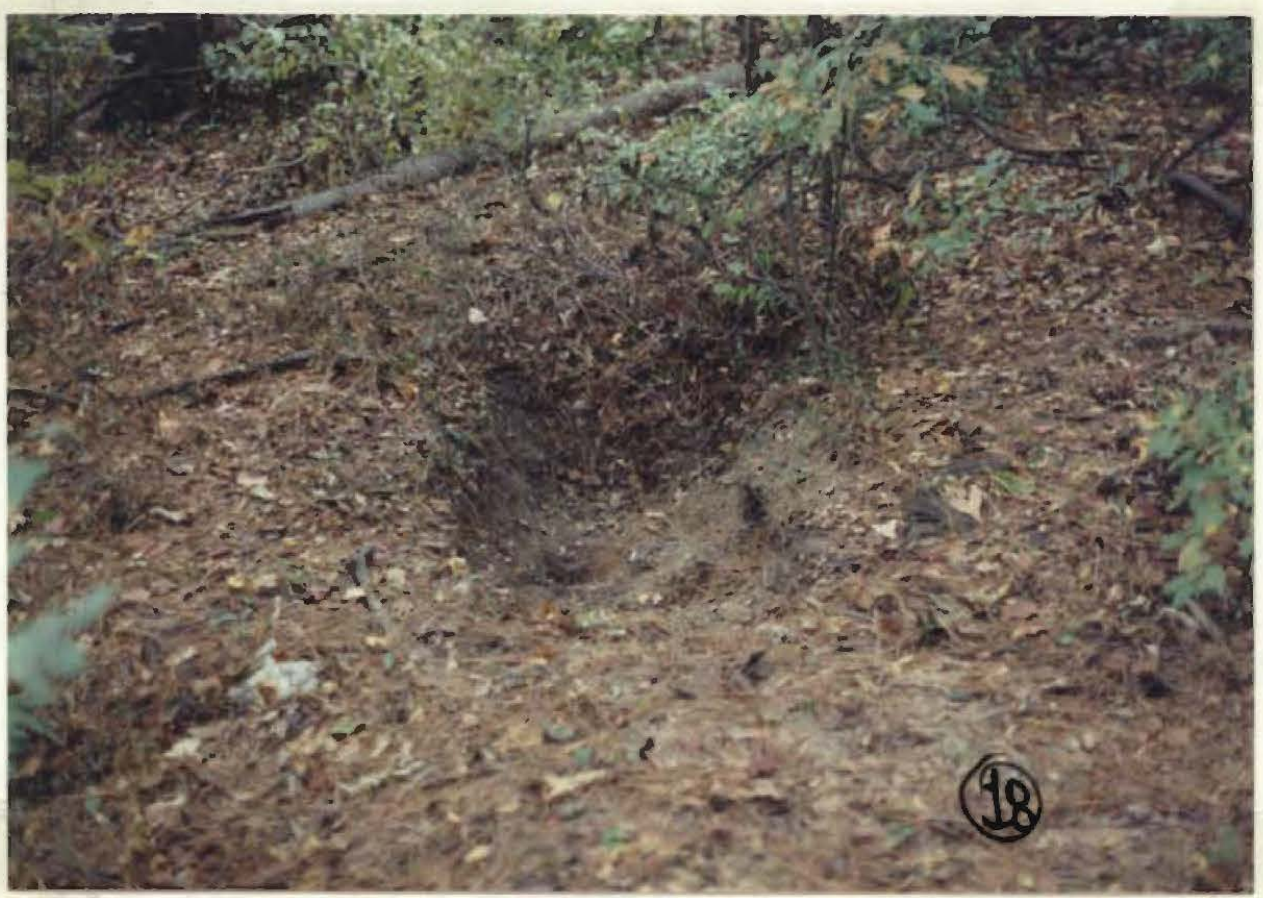

Figure 6. View of open pothole (burial) at the south end of the open trench.

During this same period, the Corps of Engineers had started a program of holding the lake at flood levels for four to six months at a time to control undesirable water vegetation. The program was effective in controlling the vegetation, but the highwater 
waves are devastating to this and many other sites along the shoreline. At the Mims site (4lMR4), for example, about $3 \mathrm{~km}$ east of Camp Joy, over $8 \mathrm{~m}$ of shoreline in one area of the site has recently eroded away.

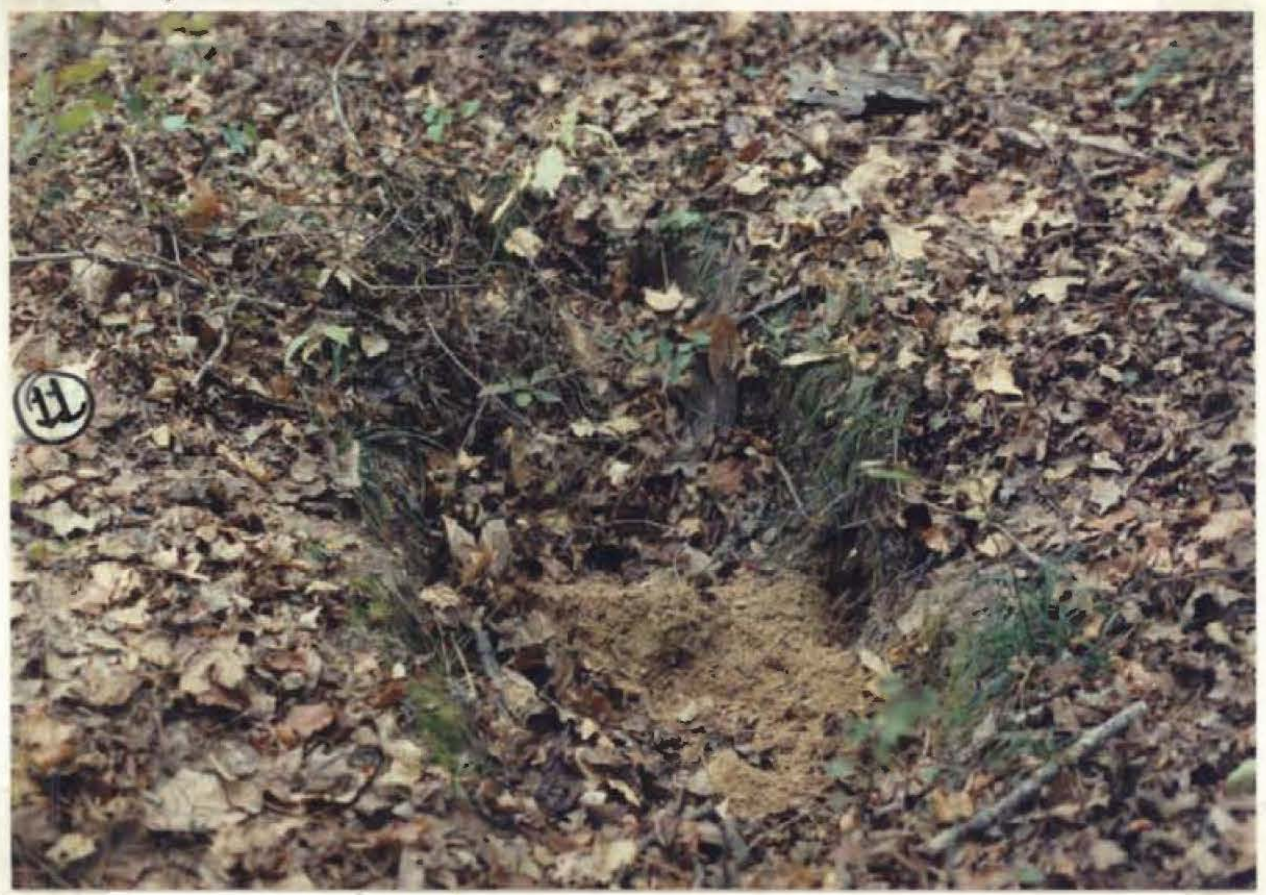

Figure 7. Open pothole (burial) on the lower terrace, $30 \mathrm{~m}$ north of east platform corner.

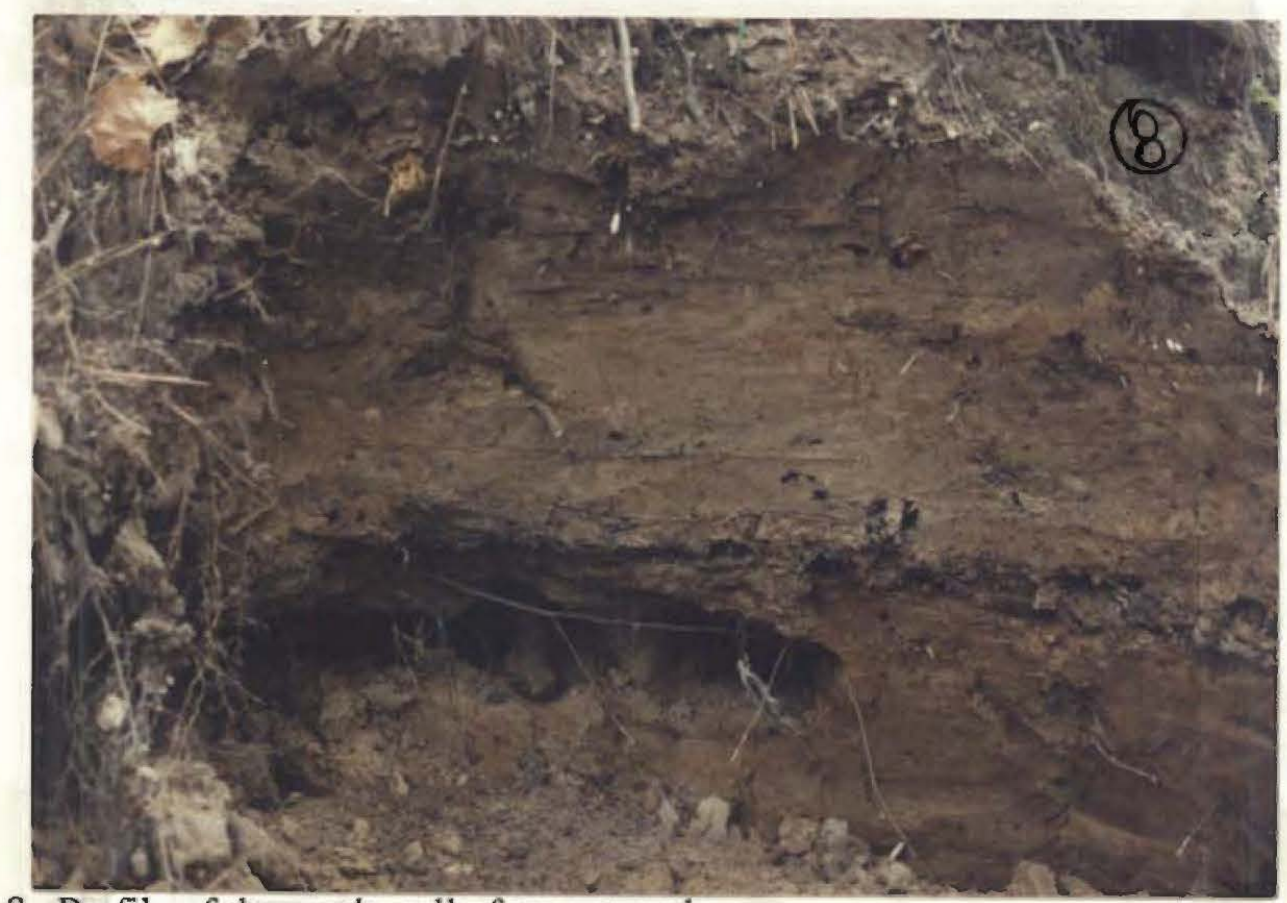

Figure 8. Profile of the north wall of open trench.

Profiling of the pothunter trench disclosed a layer of charcoal in the trench walls that apparently extened across the mound area at the level where the top mound and 
platform mound are conjoined. Profile \#1 (Figure 8), the north profile, was taken from the remnant of the 1988 open pit where it intersects with the now open trench (see Figure 3 and 4). Noteworthy is the charcoal lens.

Profile \#2 (Figure 9A) was taken from the east wall of the open trench and profile \#3 (Figure 9B) was taken from the west wall (see Figure 4). Both profiles show the charcoal lens some $60 \mathrm{~cm}$ below the organic horizon or humus intermixed with a clay to mixed clay cap. A sandy loam overlies the charcoal lens and clay fill. The mixture of sediments in the fill is evidence for an artificial mound. Individual basket loads of sediments were also observed in the profiles.
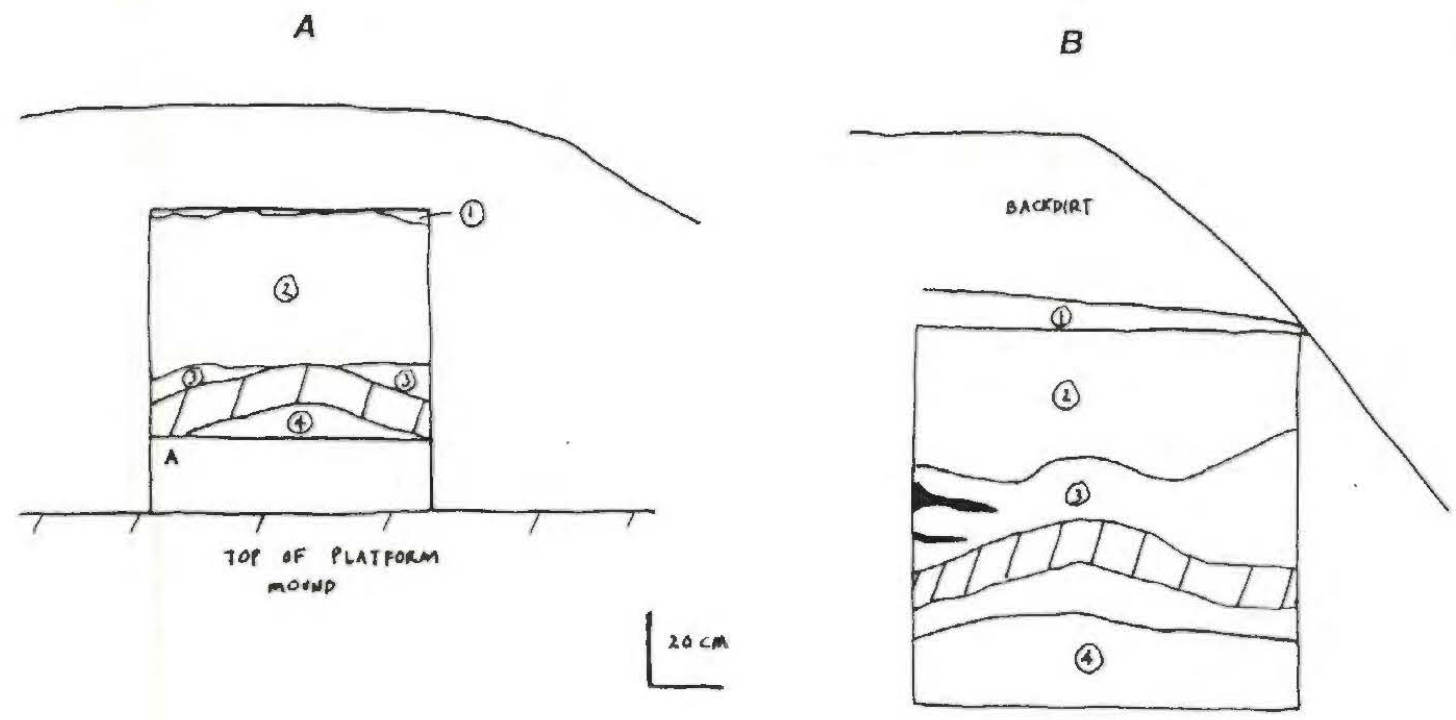

Figure 9. East (A) and west (B) wall trench profiles. (A), Zone 1: remnant of humus; Zone 2: sandy loam with clay flecks; Zone 3: clay; Zone 4: clay; diagonal-hatched zone: charcoal lens and stain; $\mathrm{A}$ is a plain sherd; (B), Zone 1: humus; Zone 2: dark sandy loam; Zone 3: light sandy loam with clay flecks and gray lens; Zone 4: sandy clay loam; diagonal-hatched zone: light charcoal stain in a mixed clay-loam fill.

\section{ARTIFACTS}

A very small assemblage of cultural material was noted at the Camp Joy mound, including three ceramic sherds and one lithic flake (Figure 10). These are individually described, as follows: 
Figure 10a: Brushed body sherd. It was found at the base of the pothole (burial) on the lower terrace, north of the mound (see Figure 4). Temper: grog and shell.

Figure 10b: Plain body sherd. It was encountered in the east profile wall, located $9 \mathrm{~cm}$ below the charcoal lens (see Figure 9A). Temper: grog.

Figure 10c: Heavily sooted brushed body sherd. It was found $10 \mathrm{~cm}$ below the platform mound surface in the wall of a $25 \mathrm{~cm}$ deep drainage ditch dug by pothunters from the northeast end of the open trench eastward across the platform mound (see Figure 4). Temper: grog and shell.

Figure 10d: Lithic flake. Made of a local chert, it was noted in the mound fill $10 \mathrm{~cm}$ above the charcoal lens, and $15 \mathrm{~cm}$ south of the west profile (see Figure 4).

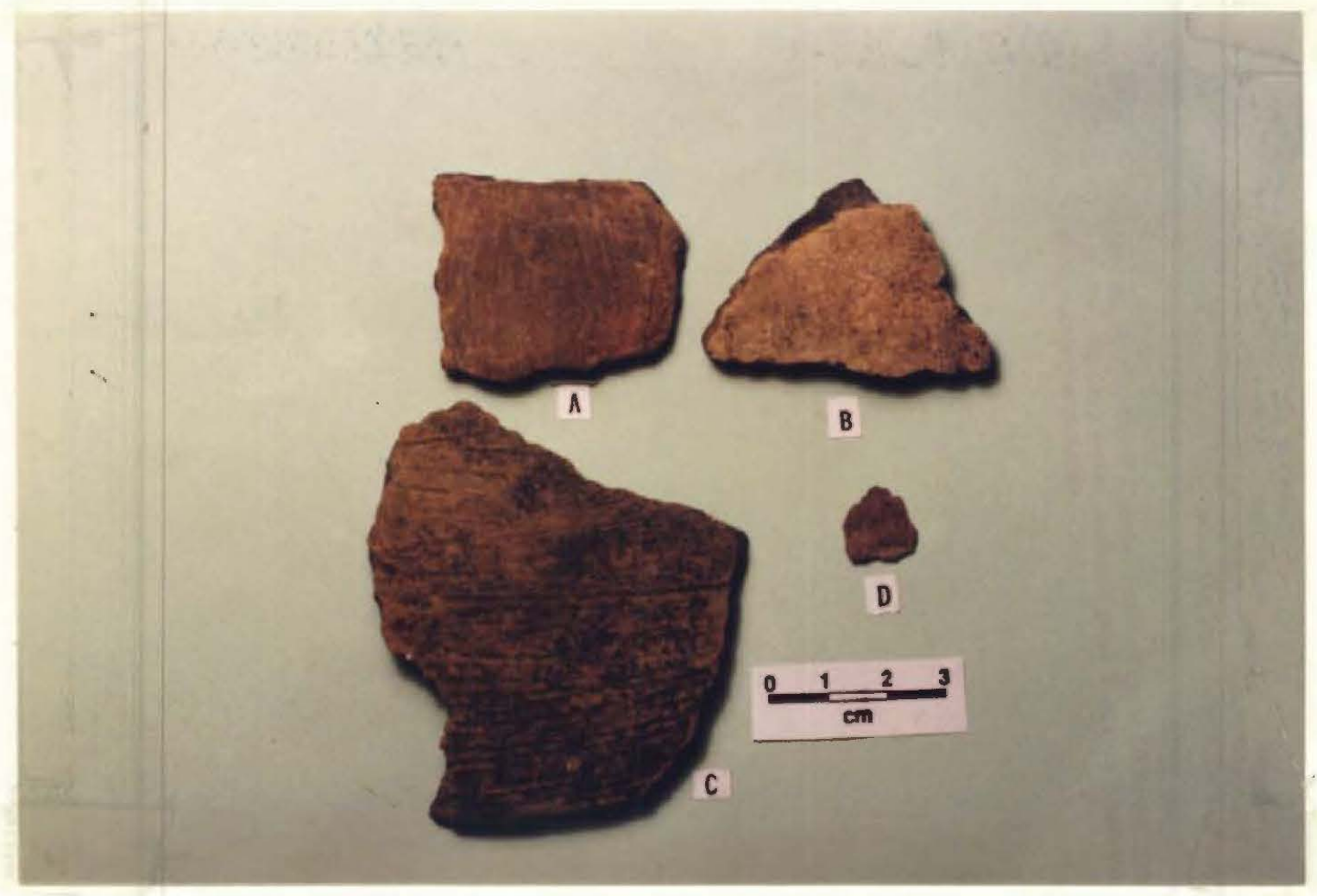

Figure 10. Artifacts from the Camp Joy Mound.

\section{LOCAL COMPARISONS}

There are nine known archeological sites in the immediate Camp Joy Mound area recorded at the Texas Archeological Research Laboratory (TARL): 41UR9, Sam Gray \#1; 41UR10, Harroun; 41UR11, Dalton; 41UR12, Jake Martin; 41UR13, Watkins; 41UR14, Sam Gray \#2; 41UR15, Cunliffe; 41UR16, Mosquito Hollow; and 41UR18, W.S. Chasteen. All nine sites were excavated by the University of Texas at Austin between 1957 
and 1960 during the Ferrell's Bridge Reservoir project under the administration of Edward B. Jelks and E. Mott Davis.

The research on Late Caddoan mounds and occupation sites of the Whelan complex (now phase) was perhaps the greatest contribution of the Ferrell's Bridge Reservoir project (Davis 1958; Jelks and Tunnell 1959). Davis (1958) believed the Whelan complex to be contemporaneous with the Bossier focus (or phase) (Thurmond 1990:25).

Except for the Jake Martin and Mosquito Hollow sites, which were principally occupied during Archaic times, the remaining seven sites are believed to have Whelan complex or phase occupations. This is based on an analysis of burial goods, arrowpoint types, and ceramic vessel decorative styles (Thurmond 1990). Most notably, Whelan phase sites have considerable quantities of sherds from brushed utility jars (Thurmond 1990:228), like the sherds found at Camp Joy Mound.

Six Whelan phase mounds are known to exist in the Camp Joy Mound area; the mounds probably all covered associated structures. There were four mounds at Harroun, one at Dalton, and one at the Chasteen site (Jelks and Tunnell 1959; Thurmond 1990).

Six radiocarbon dates were acquired from these sites in 1964 and 1966. Five came from the Harroun site and another is from Dalton. They range from A.D. 1325 to A.D. 1580 (Story et al. 1990). Dates from ca. A.D. 1350 to A.D. 1450 appear appropriate for the Whelan phase (Perttula 1992).

\section{CONCLUSIONS}

The Camp Joy Mound site appears to be a Caddoan two-phase or two-tiered mound that was probably constructed during the Whelan phase. The mound site will likely prove to be an important Caddo site in the Cypress Basin in its own right if it still retains some archeological integrity, and more so if it can be shown to be a ceremonial center in probable association with other known Whelan phase habitation sites and mounds.

The Fort Worth District of the Corps of Engineers and the THC have met to discuss various methods of site protection and treatment for the Camp Joy Mound. The site is being impacted by lakeshore erosion, and pothunting continues to be aproblem at Lake $\mathrm{O}^{\prime}$ the Pines, so the site will be difficult to protect. Archeological excavations should be conducted at the site if no preservation alternatives seem feasible.

\section{ACKNOWLEDGMENTS}

I would like to thank Kevin King and Bo Nelson for their assistance with site recording; Kevin for the photography and for pulling a tape through the underbrush, and Bo for photography and excellent help in doing the profiles. I would especially like to 
thank Tim Perttula. Without his help and constant proding, this report would not have been written.

\section{REFERENCES}

Davis, E. Mott 1958

The Whelan Site, a Late Caddoan Component in the Ferrell's Bridge Reservoir, Northeastern Texas. Report submitted to the National Park Service by the University of Texas, Division of Research in Anthropology, Austin.

Jelks, Edward B. and Curtis D. Tunnell 1959

The Harroun Site, A Fulton Aspect Component of the Caddoan Area, Upshur County, Texas. Archeology Series 2. Department of Anthropology, The University of Texas, Austin.

Perttula, Timothy $\mathrm{K}$. 1992

"The Caddo Nation": Archaeological and Ethnohistoric Perspectives. University of Texas Press, Austin.

Smith, Bruce D. 1985

Introduction to the 1985 Edition. In Report on the Mound Explorations of the Bureau of Ethnology, by Cyrus Thomas, pp. 5-19. Smithsonian Institution Press, Washington, D.C.

Story, Dee Ann, Janice A. Guy, Barbara A. Burnett, Martha D. Freeman, Jerome C. Rose, D. Gentry Steele, Ben W. Olive, and Karl J. Reinhard

1990 The Archeology and Bioarcheology of the Gulf Coastal Plain. Research Series No. 38. Arkansas Archeological Survey, Fayetteville.

Thomas, Cyrus 1894

Report on the Mound Explorations of the Bureau of Ethnology. Twelfth Annual Report of the Bureau of Ethnology. Government Printing Office, Washignton, D.C.

Thurmond, J. Peter 1990 Archeology of the Cypress Creek Drainage Basin, Northeastern Texas and Northwestern Louisiana. Studies in Archeology No. 5. Texas Archeological Research Laboratory, The University of Texas at Austin.

Turner, Mike 1993

Camp Joy Mound (41UR144). Newsletter of the Northeast Texas Archeological Society, Volume 2, No. 1, pp. 6-7. 